\title{
An Experimental Study on Electroless Nickel Plating on Alumina Ceramic
}

\author{
R. K. Gupta ${ }^{1, *}$, Anjali Nihore ${ }^{2}$, P. Ram Sankar ${ }^{1}$, P. Ganesh ${ }^{1}$, R. Kaul ${ }^{1}$ \\ ${ }^{1}$ Raja Ramanna Centre for Advanced Technology, Indore- 452013, MP, India \\ ${ }^{2}$ Project Student SGSITS Indore, MP, India
}

Received December 4, 2020; Revised January 22, 2021; Accepted February 24, 2021

\begin{abstract}
Cite This Paper in the following Citation Styles
(a): [1] R.K. Gupta, Anjali Nihore, P. Ram Sankar, P. Ganesh, R. Kaul, "An Experimental Study on Electroless Nickel Plating on Alumina Ceramic," Chemical and Materials Engineering, Vol. 8, No. 1, pp. 1 - 6, 2021. DOI: 10.13189/cme.2021.080101.
\end{abstract}

(b): R.K. Gupta, Anjali Nihore, P. Ram Sankar, P. Ganesh, R. Kaul (2021). An Experimental Study on Electroless Nickel Plating on Alumina Ceramic. Chemical and Materials Engineering, 8(1), 1 - 6. DOI: 10.13189/cme.2021.080101.

Copyright $(2021$ by authors, all rights reserved. Authors agree that this article remains permanently open access under the terms of the Creative Commons Attribution License 4.0 International License

\begin{abstract}
In this paper a low temperature metallization i.e. standardization of electroless Ni plating on alumina ceramic is summarized. It includes three main steps (i) pre-treatment, (ii) activation and (iii) $\mathrm{Ni}$ plating. Pre-treatment includes degreasing with non-silicate soap solution followed by ultrasonic cleaning in acetone and etching the alumina surface to generate roughness for making it suitable for adhesion. Etching has been obtained by immersion in $10 \% \mathrm{NaOH}$ at $50^{\circ} \mathrm{C}$ for 10 minutes and $50 \%$ $\mathrm{HF}$ for 15 minutes at room temperature. Activation of the surface is the most important step before electroless plating on alumina ceramic. Activation has been achieved with Ginplate 442 (commercial chemical) by immersing the alumina specimen for 5 minutes at room temperature. Activated alumina samples have been used for electroless Ni plating in Ginplate 418 bath at $88^{\circ} \mathrm{C}$.Uniform, densely compact coating has been achieved as revealed by SEM image. XRD plot confirms the presence of metallic nickel together with phases of $\mathrm{Ni}_{2} \mathrm{P}, \mathrm{NiP}, \mathrm{Ni}_{3} \mathrm{P}$ confirming the nickel phosphite based plating. Subsequently, tube to tube joining of these metallized alumina ceramic tubes has been conducted through vacuum brazing process with copper silver eutectic alloy $(28 \mathrm{Cu}-72 \mathrm{Ag})$ whose cross section showed good joint with excellent wettability of $\mathrm{Cu}-\mathrm{Ag}$ with Ni plating.
\end{abstract}

Keywords Low Temperature Metallization, Electroless Nickel Plating, Pre-treatment, Activation

\section{Introduction}

Electroless nickel is a coating used for engineering purposes, normally used because of excellent corrosion and wear resistance. Electroless metal based plating is generally used to deposit the metal without applying potential or electric current. Hot acid hypophosphite based baths are mostly used to plate steel and other metals, whereas warm alkaline hypophosphite based baths are used for plating plastic material and non-metallic ceramics. Electroless nickel deposition is also used on aluminum substrates to provide a solderable surface and is used with molds and dies to improve lubricating properties. Due to these properties, electroless nickel plating got many important applications, including those in petrochemical, chemical application, ceramic plastics, optics purpose, printing, mining, aerospace industry, automotive industry, electronics use, computers/laptops, textiles industry, paper and food machinery parts [1]. Electroless Ni plating has many advantages like uniform plating, solder ability and braze ability with some limitations like less adherence, plating rate not so fast as compared to electroplating. Plastic material and ceramics insulator material need proper and suitable cleaning/pre-treatment for metallic depostion using electroless bath [2]. The microstructures and other properties of electroless Ni coating which is in the form of of Ni-P (EN) depend on the phosphorous content alloyed in the deposit [3,4]. The mechanical and tribological properties of these coatings can be further tailored by adding hard particles [5], thermal treatment $[3,6]$ and some dry lubricants $[7,8]$. High purity alumina 
$\left(\mathrm{Al}_{2} \mathrm{O}_{3}\right)$ material is an ultra-high vacuum (UHV) compatible ceramic which reduces eddy current losses. It shows high electrical resistance and reasonably good tensile strength \& flexural strength with low out-gassing rate and high radiation resistance [9-10].

Joining of ceramics is often an essential part of the fabrication process for ceramic components. Vacuum brazing is the universally accepted joining process for ceramics $[11,12]$. The requirement of obtaining acceptable ceramic brazed joints is met through either by metallizing mating ceramic surfaces [13-16] or by using active brazes filler. Mo-Mn metallization is the conventional method which is often used to obtain wettable ceramic surface. The multi-step metallization process comprises of (i) coating of surface of the ceramic with metallization paint, (ii) drying and firing at $1723-1873 \mathrm{~K}$ in wet hydrogen atmosphere, (iii) nickel plating, followed by (iv) sinter firing at 1123-1173 K [17]. Major problems associated with Mo-Mn metallization are: (i) long and tedious process which requiring special skills and (ii) absence of qualified vendors. On the other hand, brazing with active braze filler is a simplified single step process [18-20] but involves formation brittle intermetallic compounds [21-23]. During brazing with active braze filler, the active metal ( $\mathrm{Ti}$ or $\mathrm{Zr}$ ) reacts with ceramic to produce an intermetallic reaction product which is wettable by the braze filler. The braze filler alloys, due to their proprietary, are quite expensive. This work standardizes a low temperature Ni metallization process for alumina ceramics and their subsequent joining through vaccum brazing with copper silver eutectic alloy $(\mathrm{Cu}-\mathrm{Ag})$. Generally plating on ceramics is a high temperature process. By using the commercial chemicals of Ginplate and required pre-treatment, a procedure is optimized for electroless $\mathrm{Ni}$ plating on alumina ceramics at comparatively low temperature. Electroless nickel plating is a simple, easy and better option than electroplating since we get uniform and thick nickel plating without applying any external current. This process may prove to be of great use in industrial applications.

In this respect, present experimental study was taken up with an objective to evaluate electro-less nickel plating as an alternative route for ceramic metalllization which is adaptable on the shop floor.

\section{Experimental Details}

Alumina $\left(\mathrm{Al}_{2} \mathrm{O}_{3}\right)$ tubes with dimensions (Height $=20 \mathrm{~mm}$; Diameter $=20 \mathrm{~mm}$ ) were used as a substrate for electroless Ni plating for low temperature metallization as shown in the Fig.1.

\subsection{Pre-treatment}

Pre-treatment involves, degreasing with soap cleaning in non-silicate bath and ultrasonic cleaning in acetone for
10 minutes. Ultrasonic cleaned specimens were immersed in $10 \% \mathrm{NaOH}$ solution at temperature $50^{\circ} \mathrm{C}$ for 10 minutes followed by rinsing with distilled water. These specimens were etched in $50 \% \mathrm{HF}$ for 15 minutes followed by rinsing with distilled water.

\subsection{Activation}

Commercial chemicals Ginplate 442 [24] solution was used as an activator for activating the surface. It is an acid activator used to prepare the surface before plating for promoting uniform and adherent formation of electroless coating. Activator solution was prepared by mixing $12.5 \%$ Ginplate 442 and $12.5 \%$ conc. $\mathrm{HCl}$ in distilled water. Pre-treated Alumina specimens were immersed in above activating solution for 5 minutes at room temperature (RT).

\subsection{Electroless Ni Plating}

Electroless $\mathrm{Ni}$ plating bath was prepared with commercial Ginplate 418 [25] chemicals which consist of Ginplate 418A (a solution containing Ni ion) and Ginplate 418B (a solution containing reducing agent) in the ratio of 6:9 in distilled water. $\mathrm{pH}$ of the bath was monitored between 4.6-4.9 with the addition of dilute ammonia solution. $100 \mathrm{ml}$ of the above solution was reduced to 80 $\mathrm{ml}$ by heating. Temperature of the bath was maintained at $80-90^{\circ} \mathrm{C}$. Pre-treated and activated alumina specimens were immersed in above solution for 40 minutes for $\mathrm{Ni}$ deposition.

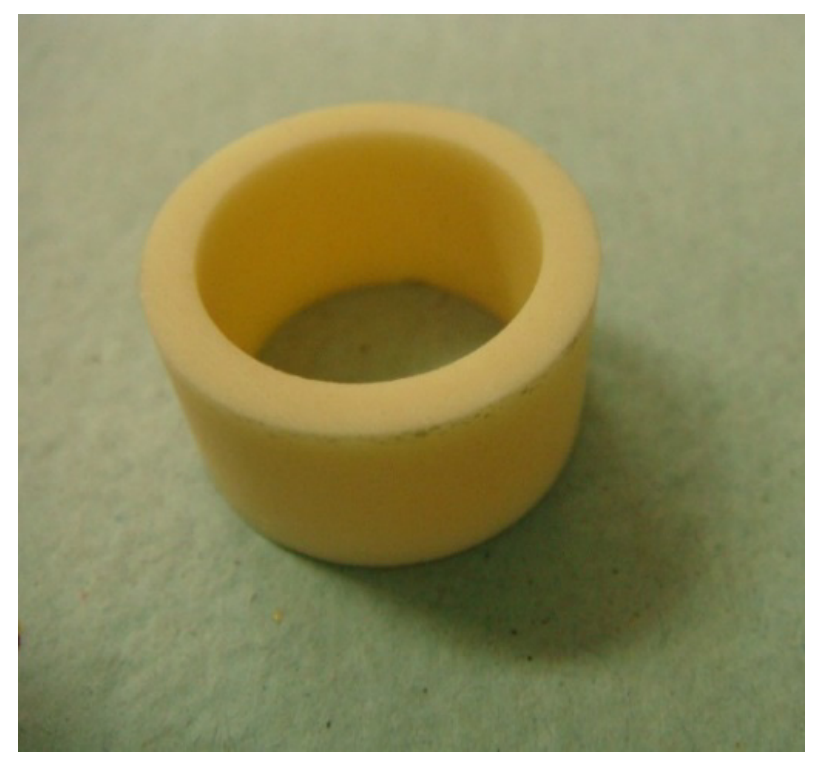

Figure 1. Alumina substrate (A12O3) used for electroless Ni plating

\subsection{Joining of Electroless Ni Plated Alumina Tubes Through Brazing}

These Ni plated alumina tubes were subsequently 
joined through brazing (a joining process) using coppersilver $(72 \mathrm{Ag} / 28 \mathrm{Cu})$ filler alloy. The brazing cycle followed during brazing in the furnace is summarized as follows.

Brazing Cycle used for joining

- Heating from room temperature to $250^{\circ} \mathrm{C} @ 3^{\circ} / \mathrm{min}$;

- Soaking at $250^{\circ} \mathrm{C}$ for $10 \mathrm{~min}$;

- Heating from $250{ }^{\circ} \mathrm{C}$ to $550{ }^{\circ} \mathrm{C} @ 3^{\circ} / \mathrm{min}$;

- Soaking at $550^{\circ} \mathrm{C}$ for $15 \mathrm{~min}$;

- Heating from $550{ }^{\circ} \mathrm{C}$ to $760{ }^{\circ} \mathrm{C} @ 3 \%$ min;

- Soaking at $760^{\circ} \mathrm{C}$ for $20 \mathrm{~min}$,

- Heating from $760{ }^{\circ} \mathrm{C}$ to $800{ }^{\circ} \mathrm{C} @ 5^{\circ} / \mathrm{min}$;

- Soaking at $800^{\circ} \mathrm{C}$ for $1 \mathrm{~min}$, followed by

- Furnace cooling.

\subsection{X-ray Diffraction and Microstructure Analysis}

X-ray diffraction (XRD) of Ni plated alumina specimen were performed to confirm the presence of $\mathrm{Ni}$ plating. SEM image was recorded to observe the plating uniformity and surface topology. Microstructure of cross section of braze joint was analyzed through OLYMPUS make optical microscope.

\section{Results and Discussion}

In the pre-treatment step, alumina tubular specimens were first cleaned with non-silicate soap solution having good detergency to remove the oil grease and fingerprints followed by ultrasonic cleaning with acetone to remove all the contaminating particles. Etching of the specimen by $10 \% \mathrm{NaOH}$ and $50 \% \mathrm{HF}$ generated rough surface and making it suitable for adhesion of the ions and developing active sites. These etched specimens were further exposed to Ginplate 442 activator where stannous and palladium salts may form a layer so that metallisation process is initiated to promote the formation of the electroless deposits with good conductivity (Fig 2).

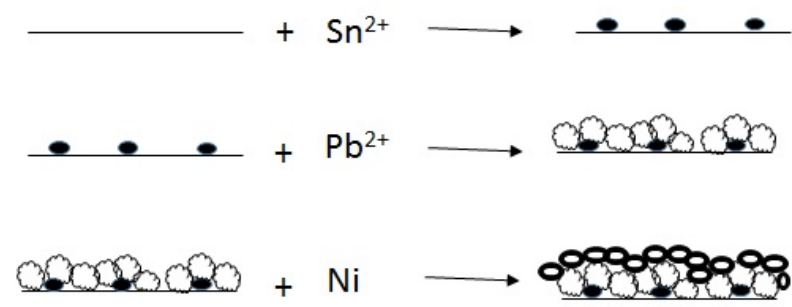

Figure 2. Schematic showing activation and Ni plating

After activation these alumina specimens were immersed into Ginplate 418 electroless Ni bath for 40 minutes at $88^{\circ} \mathrm{C}$. Uniform plating was obtained. Fig 3 and Fig 4 show alumina tubes and buttons plated with above procedure and good repeatability was observed.

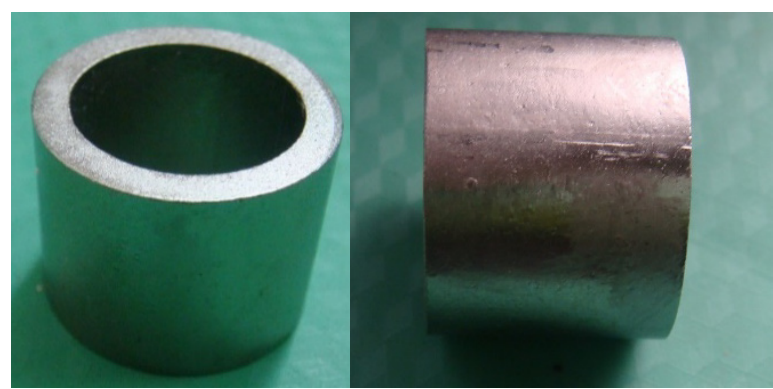

Figure 3. Electroless Ni plated Alumina tube specimen (Left) Vertical View; (Right) Horizontal view

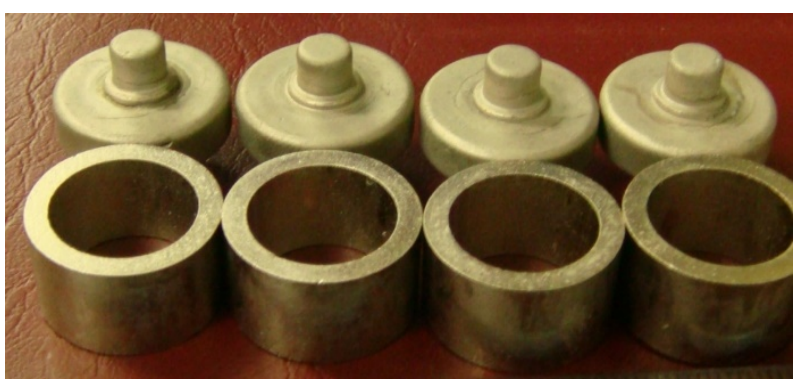

Figure 4. Electroless Nickel plating on tubes and buttons

These electroless Ni plated alumina ceramic tubes were joined through brazing in vacuum furnace. Filler used was $\mathrm{Cu}-\mathrm{Ag}$ eutectic alloy (CuSil) foil because it has got good wettability with $\mathrm{Ni}$. Thus bond formation can take place to form the joint. Fig.5 shows tube to tube and tube to button brazed joint and excess filler flown around the joints can also be seen.

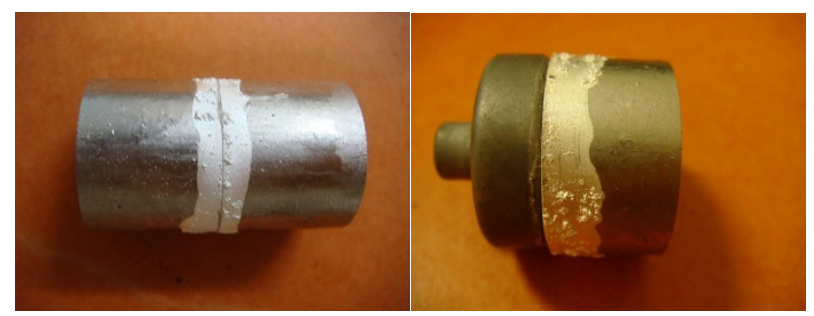

Figure 5. Brazed Joint of a Electroless Nickel Plated Tube to tube (left) and Tube to Button (right)

X-RAY diffraction analysis of these plated alumina ceramics clearly indicated the presence of metallic $\mathrm{Ni}$ peaks together with intermetallic phases of $\mathrm{Ni}_{2} \mathrm{P}$, NiP, $\mathrm{Ni}_{3} \mathrm{P}$ confirming the nickel phosphite based plating. This phosphorous based plating was observed because of presence of phosphorous content in Ginplate 418 bath. Mostly Ni is plated as NiP with electroleess means which is supported by XRD in the present case. Fig 6. shows the XRD plot of deposited Ni plating on alumina ceramic. Visual examination showed the shiny metallic coating on the alumina ceramics. The surface was conductive as examined by multimeter. Micro-structural SEM examination of electroless $\mathrm{Ni}$ deposition showed uniform deposition on the surface of alumina ceramics. Deposition is dumble shaped granular coating which covers whole 
area. Smooth and densely compacted film feature can be clearly seen in the Fig.7. Overall morphology is clearly visible in the SEM image. Cross sectional microscopic examination of this tube to tube joint shows the formation of intact joint with satisfactory wetting of filler after brazing as shown in Fig.8. Braze joint microstructure clearly shows presence of separate electroless $\mathrm{Ni}$ layer and dual phase microstructure containing copper and silver. However, coating delamination was observed from the alumina ceramic surface after exposing to the brazing cycle showing adherence issue. This is due to blister formation in the coating due to trapping of gases. These blister becomes clear visible after exposing to the brazing cycle. Fig 9 shows magnified view showing the delamination of coating and blister present on the surface. Due to this delamination, the above tube to tube joint could not pass the helium leak test and showed gross leak of the order of $1 \times 10^{-3} \mathrm{mbar} . \mathrm{lit} / \mathrm{sec}$. To avoid this problem, low temperature baking for removing trapped hydrogen is one of the option. Any alternate surface treatment (chemical or mechanical) before electro less plating to generate surface roughness may also avoid delamination and can improve the adhesion. Fig 10 presents the optical microstructures of electro less nickel plating before and after brazing cycle. Please note that defocusing of the microstructure is due to tubular specimen and no major conclusion can be drawn regarding delamination.

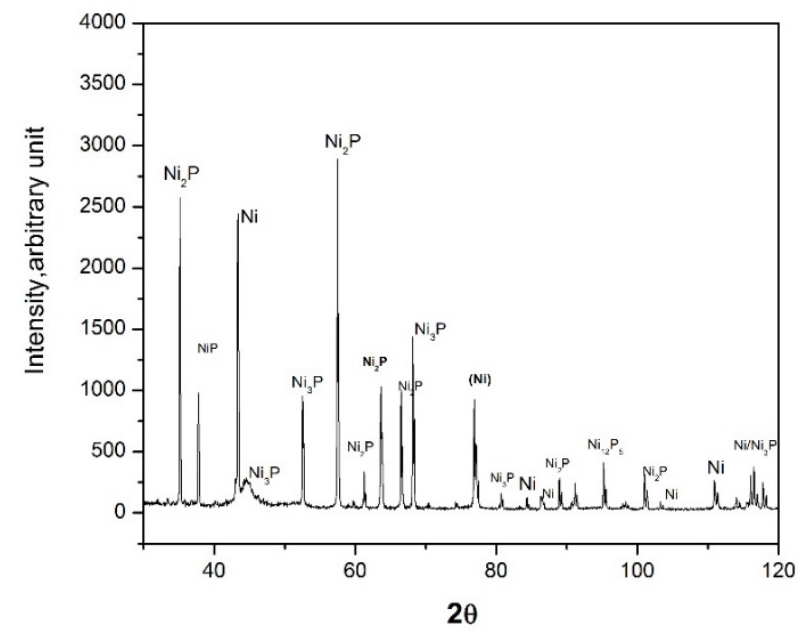

Figure 6. XRD plot of electroless Ni plating deposited on alumina.

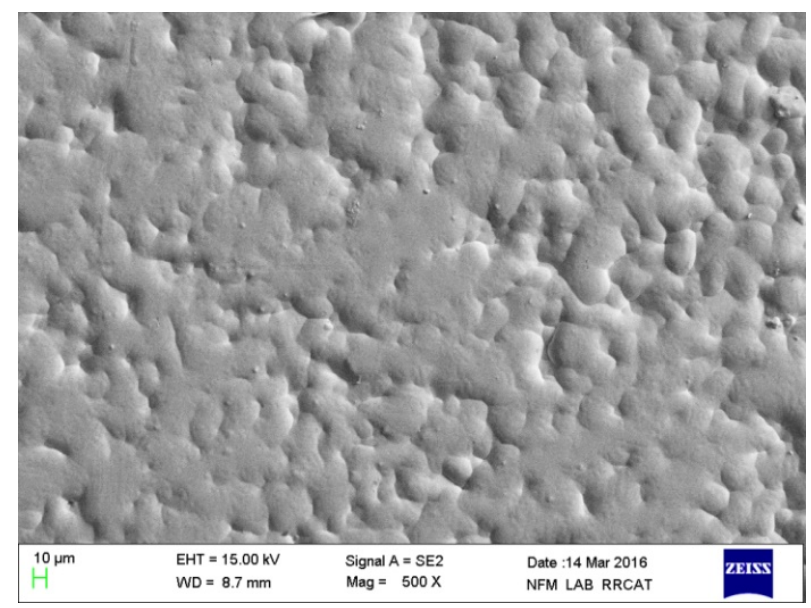

Figure 7. SEM image of electroless Ni plating

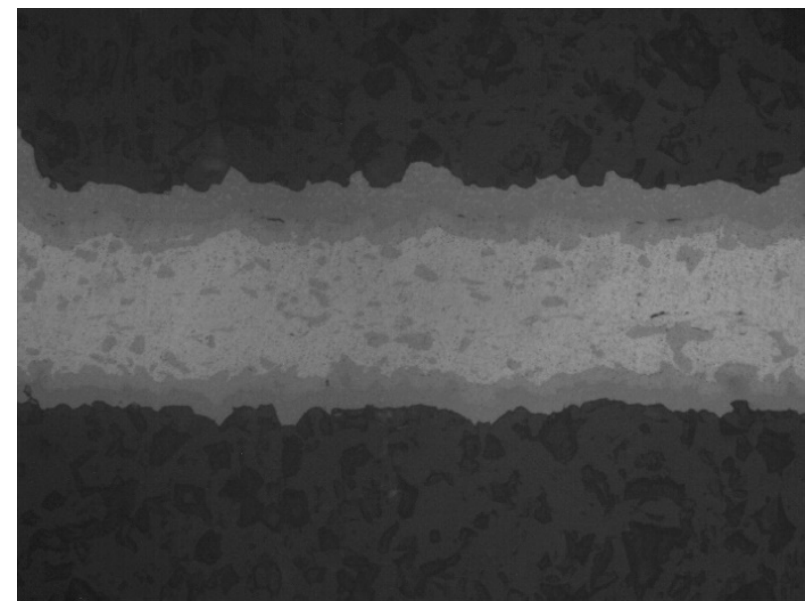

Figure 8. Microstructure of braze joint

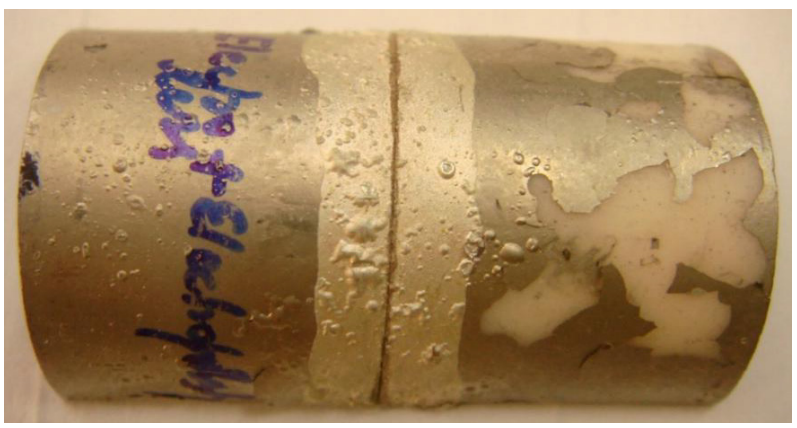

Figure 9. Magnified photograph of Electroless Nickel Plated Tube to tube braze joint showing delamination of plating after brazing due to blister formation 

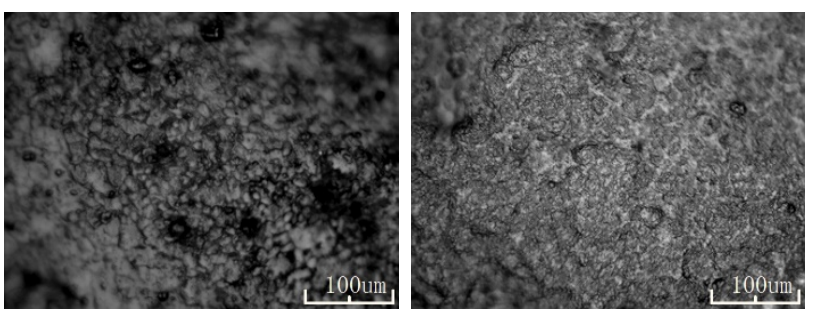

Figure 10. Optical microstructures of electroless Ni plating on alumina ceramic (left) before brazing and (right) after exposing brazing cycle

\section{Conclusions}

In this paper, an experimental study for low temperature metallization i.e. for electroless nickel plating on alumina ceramic is described. Pros and cons of the present study and its subsequent outcomes are presented. Plating process includes three main steps (i) pre-treatment,

(ii) activation and (iii) Ni plating.

(1) Pre-treatment includes degreasing with soap solution followed by ultrasonic cleaning in acetone and etching the alumina surface to generate roughness for making it suitable for adhesion. Etching has been carried out by immersion in $10 \% \mathrm{NaOH}$ at $50^{\circ} \mathrm{C}$ for 10 minutes and $50 \% \mathrm{HF}$ for 15 minutes at room temperature.

(2) Activation has been achieved with Ginplate 442 (commercial chemical) by immersing the alumina specimen for 5 minutes at room temperature.

(3) Electroless Ni plating was done in Ginplate 418 bath at $88^{\circ} \mathrm{C}$.

(4) Uniform, densely compact coating has been observed by SEM.

(5) XRD plot confirm the presence of metallic nickel together with phases of $\mathrm{Ni}_{2} \mathrm{P}, \mathrm{NiP}, \mathrm{Ni}_{3} \mathrm{P}$ confirming the nickel phosphite based plating.

(6) Joining of metallized alumina tubes, through brazing results good metallised alumina joint with excellent wettability of $\mathrm{Cu}-\mathrm{Ag}$ with $\mathrm{Ni}$ plating. However, coating delamination was observed from the alumina ceramic surface due to blister formation after exposing to the brazing cycle.

\section{Acknowledgement}

Authors are thankful to EA lab for XRD measurements and NFM Lab for SEM image. Authors are also thankful to brazing team.

\section{REFERENCES}

[1] W.D. Fields, R.N. Duncan, J.R. Zickgraf, The ASM Committee on Electroless Nickel Plating: Metals Handbook,
ASM, Metals Park, OH, pp. 219-243, 1982.

[2] Wolfgang Riedel, Electroless Nickel plating, ASM International, 1991.

[3] K.H. Hur, J.H. Jeong, D.N. Lee, Microstructure and crystallization of electroless Ni-P deposits, Journal of Materials Science, 25(5), pp.2573-2584, 1990.

[4] Y.S. Huang, X.T. Zeng, I. Annergren, F.M. Liu, Development of electroless Ni-P-PTFE-SiC composite coating, Surface and Coating Technology, 167, pp.207-211, 2003.

[5] I. Apachitei, J. Duszczyk, L. Katgerman, P.J.B. Overkamp, Electroless Ni-P composite coatings: the effect of heat treatment on the micro hardness of substrate coating, Scripta Materialia, 38(9), pp.1347-1353, 1998.

[6] G. Straffelini, D. Colombo, A. Molinari, Surface durability of electroless Ni-P composite deposits, Wear, 236, pp.179$188,1999$.

[7] Q. Zhao, Y. Liu, H. Muller-Steinhagen, G. Liu, Graded NiP-PTFE coatings and their potential applications, Surface and Coatings Technology, 155, pp.279-284, 2002.

[8] Krell A. Improved hardness and hierarchic influences on wear in submicron sintered alumina, Mater. Sci. Eng. A, 209(1), pp.156-63, 1996.

[9] D.P. Yadav, R. Kaul, P. Ganesh, Ram Shiroman, R. Sridhar, L.M. Kukreja, Study on vacuum brazing of high purity alumina for application in proton synchrotron, Materials \& Design, 64, pp.415-422, 2014

[10] https://www.rrcat.gov.in/newsletter/NL/nl2014/issue2/pdf/ A15.pdf

[11] L. Sánchez, D. Carrillo, E. Rodriguez, F. Aragon, J. Sotelo and F. Toral, Development of high precision joints in particle accelerator components performed by vacuum brazng. J. Mater. Process. Technol.,211(8), pp.1379-85, 2011

[12] C. R. Ader, C. Jensen, R. Reilly, D. Snee and J. H. Wilson, Recent experience in the fabrication and brazing of ceramic tubes for kicker magnets at FNAL. In: Proceedings of the European Particle Accelerator Conference EPAC, 2008.

[13] R. M. do Nascimento, A. E. Martinelli, A. J. A. Buschinnelim, Recent advances in metal-ceramic brazing. Cerâmica, 49(312), pp.178-98, 2003.

[14] M. G. Nicholas MG, editor, Joining of Ceramics. London: Institute of Ceramics, Chapman and Hall, pp.52-92, 1990.

[15] H. Mayer, Joining oxide ceramics. <http://www.friatec.de/c ontent/friatec/en/Ceramics/FRIALIT-DEGUSSIT-OxideCe ramics/Downloads/downloads/FA_Joining-oxide-ceramics. pdf $>$ [visited on 29.07.14].

[16] L. Reed, W. Wade, S. Vogel, R. McRae and C. Barnes, Metallurgical, research and development for ceramic electron devices (EImac), AD636950, Report No. 12, TR66-1, R/E 66-115, 1996.

[17] C. A. Walker and V. C. Hodges, Comparing metal ceramic brazing methods, Welding Journal, 87(10), pp.43-50, 2008

[18] Y. Sechi, T. Tsumura and K. Nakata, Dissimilar laser 
brazing of boron nitride and tungsten carbide, Materials and Design,31, pp.2071-2077, 2010

[19] G. Humpston and D. M. Jacobson, Principles of soldering and brazing, ASM International, pp.164-70, 1993.

[20] T. Zaharinie, R. Moshwan, F. Yusof, M. Hamadi and T. Ariga, Vacuum brazing of sapphire with Inconel 600 using $\mathrm{Cu} / \mathrm{Ni}$ porous composite interlayer for gas pressure sensor application, Mater. Des., 54, pp.375-81, 2014.

[21] https://www.twi-global.com/technical-knowledge/faqs/faqwhat-is-active-metal-brazing, FAQ: What is active metal brazing? visited on 11.02.2019.

[22] https://www.vbcgroup.com/technical-news/active-braze-all oys-and-their-applications/, Active Braze Alloys and their Applications, visited on 11.02.2019.

[23] Chia-Chin Lin, Rui-Bin Chen and Ren-Kae Shiue, A wettability study of $\mathrm{Cu} / \mathrm{Sn} / \mathrm{Ti}$ active braze alloys on alumina, Journal of Materials Science, 36, pp.2145-2150, 2001

[24] www.growel.com, Technical data sheet Ginplate activator 442

[25] www.growel.com, Technical data sheet Ginplate Ni $418 \mathrm{M}$ 